\title{
PENYULUHAN UMKM DI ERA NEW NORMAL DENGAN MEMPRIORITASKAN EKONOMI DIGITAL MARKETING
}

\author{
Febri Indra Farizki ${ }^{1)}$, Robiatus Salamah"1), Tengku Suripah Rani Mutiah"1), Widya Kusuma Wardhani ${ }^{11}$, \\ Purnama Siddi ${ }^{1)}$
}

1)Program Studi S1 Akuntansi, Fakultas Ekonomi, Universitas Islam Batik Surakarta, Surakarta, Jawa tengah, Indonesia

Corresponding author : Febri Indra Farizki

E-mail : febriindraf@gmail.com

\section{Diterima 10 November 2020, Direvisi 16 November 2020, Disetujui 16 November 2020}

\begin{abstract}
ABSTRAK
Di era new normal merupakan tahapan bagi pemerintah maupun masyarakat untuk menyelesaikan masalah ekonomi yang terjadi di segala lapisan masyarakat. Maka dengan memanfaatkan keadaan new normal ini, maka kami kelompok KKN Tematik Universitas Islam Batik Surakarta membuat kegiatan penyuluhan UMKM yang bertujuan untuk membangkitkan kembali dan meningkatkan semangat berwirausaha dengan memanfaatkan media sosial sebagai salah satu strategi dari digital marketing di Desa Jambeyan. Penyuluhan ini diikuti oleh 15 warga pemilik UMKM Dukuh Ngrejeng, Dusun Gamping, Desa Jambeyan, Kecamatan Sambirejo, Kabupaten Sragen. Dengan melaksanakan penyuluhan UMKM maka kami segenap kelompok KKN Tematik Universitas Islam Batik Surakarta menyimpulkan bahwa penyuluhan UMKM yang kami berikan kepada para pemilik UMKM di Dukuh Ngrejeng, Dusun Gamping, Desa Jambeyan, Kecamatan Sambirejo, Kabupaten Sragen memperoleh dampak perekonomian pelaku UMKM meningkat sehingga mereka mampu untuk mempertahankan kehidupannya.
\end{abstract}

Kata kunci: penyuluhan UMKM; digital marketing; new normal.

\begin{abstract}
In the new normal era, it is a stage for the government and society to solve economic problems that occur at all levels of society. So by taking advantage of this new normal situation, we, the Thematic KKN Group of the Islamic Batik Surakarta University, made a UMKM counseling activity that aims to revive and increase the entrepreneurial spirit by utilizing social media as one of the strategies of digital marketing in Jambeyan Village. This counseling was attended by 15 residents of the owner of UMKM Dukuh Ngrejeng, Gamping Hamlet, Jambeyan Village, Sambirejo District, Sragen Regency. By carrying out the UMKM counseling, the entire Thematic KKN Group of the Islamic Batik Surakarta University concluded that the UMKM counseling we gave to UMKM owners in Dukuh Ngrejeng, Dusun Gamping, Jambeyan Village, Sambirejo District, Sragen Regency had an increased economic impact so that they were able to maintain its life.
\end{abstract}

Keywords: UMKM counseling; digital marketing; new normal.

\section{PENDAHULUAN}

Indonesia mengonfirmasi kasus pertama infeksi virus corona penyebab Covid19 pada awal Maret 2020. Sejak itu, berbagai upaya penanggulangan dilakukan pemerintah untuk meredam dampak dari pandemi Covid-19 di berbagai sektor. Hampir seluruh sektor terdampak, tak hanya kesehatan. Sektor ekonomi juga mengalami dampak serius akibat pandemi virus corona (Rizal, 2020). Kegiatan ekonomi Indonesia pun terhambat karena Covid-19 yang akhirnya berdampak pada pendapatan Negara. Dampak ekonomi tidak hanya berakibat pada perusahaan bisnis besar saja. Usaha Mikro, Kecil dan Menengah (UMKM) yang ada di Indonesia memberikan pengaruh yang cukup besar, sehingga di masa pandemi ini banyak dampak negatif yang dirasakan (Crismawan, 2020).

Usaha Mikro Kecil dan Menengah (UMKM) adalah usaha produktif yang dimiliki perorangan maupun badan usaha yang telah memenuhi kriteria sebagai usaha mikro, seperti diatur dalam Peraturan Perundang-Undang No. 20 tahun 2008.

Usaha Mikro, Kecil dan Menengah (UMKM) di Indonesia memiliki peran penting dalam laju perekonomian negara terutama dalam memeratakan perekonomian, mengurangi kemiskinan, dan memberikan devisa bagi negara (Sandi, 2020) 
Usaha mikro, kecil, dan menengah (UMKM) menjadi sektor yang kena dampak cukup besar ketika pandemi Covid-19. Tak sedikit yang kolaps atau gulung tikar, sehingga membuat banyak orang kehilangan banyak pendapatan. Namun, di era New Normal, ekonomi dan terutama UMKM perlahan bangkit dan mulai gencar mencari strategi baru dalam upaya bertahan (Ramadhan, 2020).

Di masa sekarang ini tentunya penggunaan teknologi menjadi solusi yang paling tepat untuk membantu roda perekonomian UMKM tetap berjalan. Salah satu cara yang bisa dilakukan adalah melakukan pemasaran melalui media social (Reswari, 2020).

Digital marketing adalah suatu kegiatan pemasaran atau promosi sebuah brand atau produk menggunakan media digital atau internet. Tujuan digital marketing untuk menarik konsumen dan calon konsumen secara cepat. Seperti yang kita tahu, penerimaan teknologi dan internet di masyarakat sangat luas sehingga tidak heran kegiatan pemasaran secara digital dijadikan pilihan utama oleh perusahaan-perusahaan (Pangestika, 2020).

Pelaku usaha kecil dan menengah harus segera dapat beradaptasi di masa pandemi Covid-19 ini agar usaha yang dijalankan dapat terus tumbuh dan bertahan. Salah satu caranya adalah dengan mengoptimalkan teknologi digital. Berdasarkan data dari Kementerian Koperasi dan UMKM, hingga saat ini dari total 64 juta pelaku UMKM, baru sekitar 8 juta atau 13\% yang sudah terhubungan dengan dunia digital. Padahal, transaksi di dunia digital terus meningkat, terutama di masa pandemi ini, ketika pergerakan masyarakat mulai dibatasi. (Andriani, Bisnis.com, 2020).

Namun terlepas dari semua kendala, ada 3 hal penting yg harus diperhatikan dalam mendukung Digitalisasi UMKM Produktif : 1) Produksi yang dihasilkan tidak hanya harus berkualitas baik, mempunyai nilai lebih dari produk lain dan dapat bersaing di pasar tetapi juga harus memiliki proses pengemasan yang baik, 2) Di Masa PSBB menuju Masa New Normal membuat distribusi produk juga ikut terganggu yang membuat barang kiriman yang dipesan atau yang dibeli menjadi lama diterima, 3) Dengan kondisi yang terjadi saat ini ada halhal yang harus diperhatikan dalam masalah promosi (Nisa, Merdeka.com, 2020).

Dampak COVID-19 terhadap pelaku UMKM juga dialami oleh warga Dukuh Ngrejeng, Dusun Gamping, Desa Jambeyan, Kecamatan Sambirejo, Kabupaten Sragen, Provinsi Jawa Tengah yang menjadi pelaku UMKM. Ada sekitar 12 UMKM yang dimiliki oleh warga setempat. Terdiri atas usaha kuliner, ternak ikan lele dan meubel. Semua pelaku UMKM di Dukuh Ngrejeng mendapatkan dampak yang cukup besar dari pandemi COVID-19 ini, dari mulai kesulitan dalam memperoleh bahan baku, menurunnya jumlah pembeli, sampai adanya pelaku UMKM yang berhenti berwirausaha.

Kondisi inilah yang mendorong perlunya upaya untuk lebih berfokus pada pengembangan jaringan, salah satunya adalah melalui penerapan strategi pemasaran digital. Strategi ini dipilih bukan hanya karena biayanya yang lebih terjangkau bagi pelaku UMKM, akan tetapi juga pada dampak jaringannya yang lebih luas, dan dapat menjangkau segmen konsumen yang lebih beragam (Hapsoro, Palupiningdyah, \& Slamet, 2019).

Dari berbagai jenis dan kondisi UMKM, pemasaran dan penjualan online dapat dilakukan melalui platform media sosial yaitu Facebook Marketplace yang penggunaannya cukup mudah, dapat dilakukan kapanpun dan di manapun serta dapat menjangkau ke seluruh pengguna Facebook. Sehingga promosi produk UMKM dan pelayanan penjualan online dapat dilakukan dengan mudah dan cepat yang nantinya secara tidak langsung akan meningkatkan penghasilan dari pelaku UMKM (Susanto, Sari, Moses, \& dkk, 2020)

Sebagai bentuk pengabdian masyarakat serta implementasi Tri Dharma Perguruan Tinggi, Mahasiswa Universitas Islam Batik Surakarta, Fakultas Ekonomi, Prodi Akuntansi mengadakan sebuah kegiatan penyuluhan UMKM. Dalam pelaksanaannya, kegiatan penyuluhan UMKM dalam rangka mengembalikan semangat berwirausaha dan memberikan wawasan terkait strategi pemasaran dengan digital marketing yang didanai oleh iuran anggota salah satu kelompok KKN Tematik Universitas Islam Batik Surakarta 2020.

$$
\text { Tujuan diadakannya kegiatan }
$$
penyuluhan UMKM diharapkan dapat meningkatkan strategi pemasaran bagi para pelaku UMKM. Kegiatan ini ditujukan kepada para pelaku UMKM di Desa Jambeyan khususnya Dukuh Ngrejeng yang mengalami masalah dalam pemasaran maupun penjualan produk karena pandemi Covid-19. Oleh karena itu, kelompok KKN Tematik program studi Akuntansi Fakultas Ekonomi Universitas Islam Batik Surakarta mengadakan kegiatan Penyuluhan UMKM.

\section{METODE}

Kegiatan Penyuluhan UMKM yang dilaksanakan sebagai bentuk pengabdian kepada masyarakat diikuti oleh 15 warga Dukuh 
Ngrejeng, Dusun Gamping, Desa Jambeyan, Kecamatan Sambirejo, Kabupaten Sragen. Tahapan dalam penyuluhan ini :

Tahap pertama, mencari dan mengumpulkan data warga Dukuh Ngrejeng yang memiliki UMKM melalui wawancara Ketua RT 21 Dukuh Ngrejeng, Dusun Gamping, Desa Jambeyan. Syarat peserta penyuluhan yaitu : 1) warga asli Dukuh Ngrejeng; dan 2) pemilik UMKM.

Tahapan kedua, persiapan pelaksanaan penyuluhan. Persiapan dimulai dengan menata tempat yang akan digunakan penyuluhan, yakni di Basecamp KKN-T UNIBA Surakarta. Dilanjut dengan pemasangan MMT Penyuluhan UMKM dan penataan meja untuk registrasi peserta penyuluhan. Kemudian setting mikrofon, sound, dan laptop untuk media penyampaian penyuluhan. Dan diakhiri dengan gladi resik (GR) penyuluhan UMKM.

Tahapan ketiga, pelaksanaan penyuluhan UMKM. Penyuluhan UMKM dilaksanakan pada tanggal 31 Oktober 2020 yang bertempat di RT 21, Dukuh Ngrejeng, Dusun Gamping, Desa Jambeyan, Kecamatan Sambirejo, Kabupaten Sragen. Peserta penyuluhan merupakan pemilik UMKM yang berdomisili di RT 21, Dukuh Ngrejeng, Dusun Gamping. Pelaksanaan diawali dengan : 1) pembukaan oleh MC, 2) sambutan dari Ketua Panitia Penyuluhan UMKM, 3) sambutan dari Bayan Dusun Gamping, 4) penyampaian materi penyuluhan oleh pemateri yaitu ekonomi digital marketing, 5) sesi tanya jawab, dan 6) foto bersama.

Tahapan keempat, pendampingan pemasaran melalui media sosial. Dilaksanakan setelah diadakannya penyuluhan UMKM dengan cara panitia penyuluhan dibagi dengan 1 orang panitia mendampingi 2 pemilik UMKM.

\section{HASIL DAN PEMBAHASAN}

Pada saat pelaksanaan penyuluhan UMKM, peserta pengabdian masyarakat tetap memperhatikan protokol kesehatan di masa pandemi Covid-19 antara lain mencuci tangan dengan sabun dan air mengalir, menggunakan masker, dan menjaga jarak. Kegiatan penyuluhan UMKM dilakukan dalam empat tahap. Adapun hasil (output) yang didapatkan dari kegiatan penyuluhan UMKM antara lain :

1. Tahap pertama yakni permohonan izin ke Ketua RT untuk mengadakan penyuluhan UMKM dan juga meminta data warga Dukuh Ngrejeng yang memiliki UMKM.

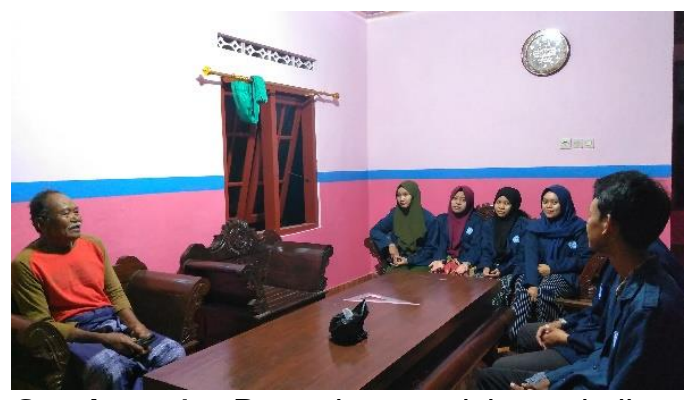

Gambar 1. Permohonan izin sekaligus wawancara ke Ketua RT 21 untuk mengadakan penyuluhan UMKM.

2. Tahap kedua yakni persiapan pelaksanaan penyuluhan UMKM yang akan diikuti oleh warga Dukuh Ngrejeng dan panitia penyuluhan UMKM.

3. Tahap ketiga yakni pelaksanaan penyuluhan UMKM yang dilaksanakan pada hari sabtu, 31 Oktober 2020. Warga yang mengikuti kegiatan ini sebanyak 15 warga Dukuh Ngrejeng dan 7 panitia penyuluhan UMKM. Para warga sangat antusias melontarkan beberapa pertanyakan terkait tentang materi penyuluhan UMKM yang telah disampaikan oleh pemateri yaitu ekonomi digital marketing dan setiap peserta penyuluhan UMKM yang bertanya akan mendapatkan door prize berupa hand sanitizer dari panitia penyuluhan UMKM.

4. Tahap keempat yakni setelah pelaksanaan penyuluhan UMKM, panitia penyuluhan UMKM mengadakan pendampingan pemasaran melalui media sosial kepada peserta penyuluhan UMKM. Peserta penyuluhan UMKM sangat merasakan perbedaan sebelum dan setelah memasarkan produknya melalui media sosial. Setelah produk pemilik UMKM dipasarkan melalui media sosial, perekonomian pemilik UMKM Dukuh Ngrejeng meningkat pesat.

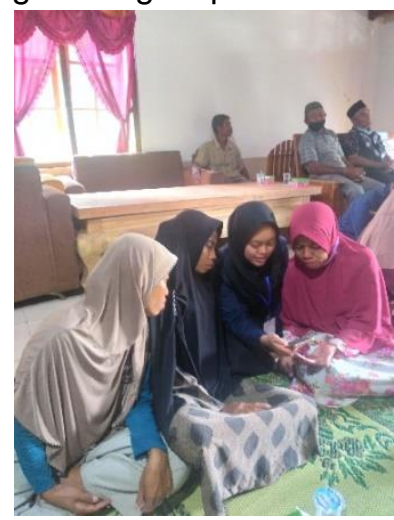

Gambar 2. Pendampingan pemasaran melalui media sosial 


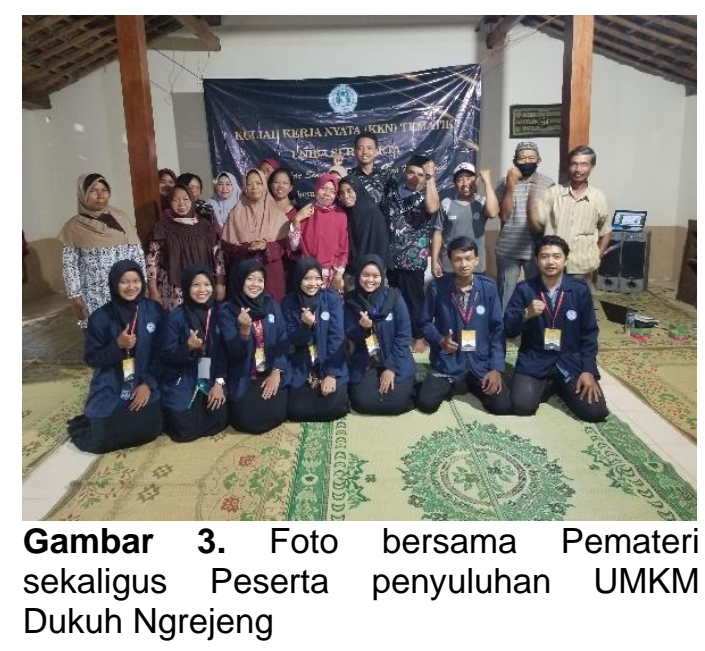

\section{SIMPULAN DAN SARAN}

Berdasarkan hasil dari penyuluhan UMKM oleh KKN-T UNIBA SURAKARTA 2020 yang dilakukan di Dukuh Ngrejeng, Dusun Gamping, Desa Jambeyan, Kecamatan Sambirejo, Kabupaten Sragen tentang ekonomi digital marketing disimpulkan bahwa kegiatan penyuluhan UMKM dengan mengundang warga masyarakat sekitar khususnya para pemilik UMKM dapat membangkitkan kembali semangat warga dalam menjalankan kembali usahanya melalui pemanfaatan media sosial juga memberikan wawasan untuk meningkatkan strategi pemasaran. Hal tersebut berdampak pada ekonomi masyarakat yang mengalami peningkatan. Saran dari kami adalah untuk memperluas jangkauan peserta penyuluhan agar ilmu tersampaikan kepada masyarakat luas.

\section{UCAPAN TERIMA KASIH}

Ucapan terima kasih kami sampaikan kepada semua pihak yang telah membantu jalannya acara penyuluhan UMKM melalui media sosial sehingga dapat berjalan dengan lancar sesuai yang diharapkan. Tak lupa kami berterima kasih kepada Ketua RT 21 atas kontribusinya dalam membantu mengumpulkan warga masyarakat Ngrejeng khususnya para pemilik UMKM. Ucapan terima kasih juga kami sampaikan kepada Pak Bayan Dusun Gamping, Ketua RT 20, RT 21, dan RT 22, serta warga masyarakat Dukuh Ngrejeng yang telah berkenan hadir dalam acara penyuluhan, sehingga acara dapat terlaksana dengan baik.

\section{DAFTAR RUJUKAN}

Andriani, D. (2020, September 08). Retrieved from Bisnis.com: https://ekonomi.bisnis.com/read/20200 908/12/1288568/umkm-didorongadaptasi-di-masa-pandemi-go-digital

Crismawan, A. B. (2020, Juli 28 ). Retrieved from Genial: http://genial.id/read- news/pengaruh-covid19-terhadapumkm-di-indonesia

Hapsoro, B. B., Palupiningdyah, \& Slamet, A. (2019). Peran Digital Marketing sebagai Upaya Peningkatan Omset Penjualan Bagi Klaster UMKM di Kota Semarang. ABDIMAS, 117-120.

Nisa, R. K. (2020, Agustus 31). Digitalisasi UMKM Produktif di Masa Pandemi. Retrieved November 16, 2020, from merdeka.com:

https://www.merdeka.com/peristiwa/di gitalisasi-umkm-produktif-di-masapandemi.html

Pangestika, W. (2020, Januari 01). Pengertian, Kelebihan, Jenis dan Strategi Digital Marketing. Retrieved November 16, 2020, from jurnal entrepreneur: https://www.jurnal.id/id/blog/mengenaldigital-marketing-konsep-danpenerapannya/

Ramadhan. (2020, Juli 09). Retrieved from PT Muda Mudi Berkarya Sejahtera: https://asumsi.co/post/strategipemulihan-ekonomi-umkm-di-masanew-normal

Reswari, D. M. (2020, April 21). Bagaimana Cara UKM Menjaga Produktivitas di Tengah Imbauan PSBB? Retrieved november 16, 2020, from jurnal entrepreneur:

https://www.jurnal.id/id/blog/cara-ukmmenjaga-produktivitas-di-tengahimbauan-psbb/

Rizal, J. G. (2020, Agustus 11). KOMPAS. Retrieved from Kompas.com: https://www.kompas.com/tren/read/20 20/08/11/102500165/pandemi-covid19-apa-saja-dampak-pada-sektorketenagakerjaan-indonesia-?page=all

Sandi, F. B. (2020, Juni 24). Peran UMKM di Indonesia yang Perlu Anda Ketahui. Retrieved November 16, 2020, from pajak: https://www.onlinepajak.com/seputar-pph-final/peranumkm

Susanto, A., Sari, C. A., Moses, D. R., \& dkk. (2020, Januari). Implementasi Facebook Marketplace untuk Produk UMKM sebagai Upaya Peningkatan Pemasaran dan Penjualan Online. Abdimasku, 3, 42-51. 